\title{
Interview med klimaminister Martin Lidegaard
}

Den danske regerings ansigt i de internationale klimaforhandlinger er klimaminister Martin Lidegaard. POLITIK har haft lejlighed til at interviewe ministeren om udsigterne til en ny klimaaftale i 2015 og nytten af hele FN-processen, der indtil nu ikke har leveret en samlet klimaaftale. Martin Lidegaard har tidligere, da han var direktør i den grønne tænketank Concito, udtalt sig opgivende om FN-processen, som han tilbage i 2010 konstaterede var kørt ubehjæelpeligt fast. Siden har han fået et mere positivt syn på FN-processen, som ministeren dog samtidig vurderer ikke kan stå alene. FN-processen skal understøttes af direkte handlingsorienteret samarbejde mellem lande, som skal bidrage til at sikre, at de globale reduktionsindsatser ikke går i stå, mens verdens lande forsøger at forhandle sig frem til en samlet klimaaftale i 2015.

POLITIK: Hvorfor har vi stadig brug for $F N$-sporet med alle COP-møderne, nair det efter 20 àr stadig ikke har kunnet levere en global aftale med reduktionsforpligtelser for alle stater, der kan bremse den globale opvarmning?

Martin Lidegaard: Det er forståeligt, at FN-sporet for mange kan virke nyttesløst, men det er det ikke. FN-sporet er det eneste forum, vi overhovedet har, der ansvarliggør stater, og det er det eneste forum, hvor staterne faktisk er blevet enige om reduktionsforpligtelser. Og det nytter noget. Selvom det er små skridt, der bliver taget - så bliver der dog taget nogle. Over 90 lande har indtil videre givet deres bud på en reduktionsindsats i kraft af deres forpligtelser fra COP15 i København. Selvom de ikke er juridisk bindende, så er det væsentlige politiske tilkendegivelser. FN-sporet er samtidig det eneste forum, der har den legitimitet og de institutionelle rammer, der var nødvendige for, at verdens lande under COP17 i Durban i 2011 kunne blive enige om et mandat til en færdigforhandling af en global aftale i 2015, hvor samtlige lande skal have juridisk bindende reduktionsforpligtelser fra 2020. Og så må vi ikke glemme, at $\mathrm{FN}$-sporet er det eneste, der indeholder tilsagn om mobilisering af den klimafinansiering, som gør det muligt at gennemføre klimatiltag i ulandene i et omfang, der står mål med udfordringerne. Så på trods af forhandlingernes træghed må vi acceptere, at der bare ikke findes et alternativ med samme globale rækkevidde. Men det står også klart, at det klassiske FN-spor ikke kan stå alene. Vi har også brug for at påvirke de enkelte lande, inden de drager til klimatopmøder, og derfor arbejder vi i mit ministerium også direkte med en række vækstøkonomier med det formål at bidrage med danske erfaringer på energiområdet og påvise, at den grønne omstilling hverken er dyr eller besværlig.

POLITIK: Hvilke faktorer bevirker, at der ikke er sket grundlaggende fremskridt $i$ klimaforhandlingerne?

Martin Lidegaard: Jeg er ikke enig i, at der ikke er sket fremskridt i klimaforhandlingerne. Foruden enigheden fra COP15 om, at den globale gennemsnitstemperatur ikke må stige mere end 2 grader i forhold til det førindustrielle niveau, så har mere end 90 lande indmeldt reduk- 
tionstilsagn, og ilandene har forpligtet sig til at bidrage med 100 mia. USD i klimafinansiering årligt fra 2020. Og så blev man jo på COP17 enige om, at man senest 2015 skal indgå en global aftale med bindende reduktionsforpligtelser for alle lande fra 2020. Det går fremad, om end langsomt. Når det er sagt, så er det klart, at der er mange interesser på spil internationalt, som medfører udfordringer for, at alle verdens lande kan blive enige om at tilslutte sig en juridisk bindende aftale med et tilstrækkeligt ambitionsniveau. Selvom man mange steder efterhånden har fået øjnene op for, at den grønne omstilling betaler sig - også økonomisk, så ligger der stadig en barriere for mange $i$, at omstillingen ofte kræver investeringer her og nu.

POLITIK: Du har tidligere udtalt dig opgivende om FNsporet, som du tilbage i 2010 havdede var kort fast. Hvad har fäet dig til at andre din opfattelse af COP15-resultatet fra efteråret 2010 til i dag? Og hvordan adskiller situationen efter COP17 sig fra opløbet til COP15, hvor der også indgik en plan for en internationalt bindende aftale for alle lande?

Martin Lidegaard: De internationale klimaforhandlinger går for langsomt, det er der ingen tvivl om, og hvis ikke landene finder en hel anden vilje til forhandling og forandring frem, bliver det meget svært at nå målsætningen om to grader. Men det er ikke det samme, som at forhandlingerne er gået i stå. Uanset at man ikke på COP15 fik den klimaaftale, som mange havde håbet på, og uanset at der i tiden efter COP15 var en slukøret stemning, også hos mig, så ændrer det ikke ved, at der er sket en række fremskridt, som jeg allerede har nævnt. Det, der for mig adskiller sig fra processen op til COP15, er, at man nu ikke blot er enige om, at der skal indgås en ny klimaaftale, men også at den skal indeholde forpligtelser for alle lande. Derfor mener jeg også, at forhandlingerne skal understøttes og drives frem i alle relevante fora og ved direkte handlingsorienteret samarbejde mellem lande. Det gør vi fra dansk side gennem det vi i mit ministerium kalder handlingssporet - og som dækker over en sammenhængende strategisk samarbejdsindsats i forhold til en række vækstøkonomier og tematisk dansk støtte til fremme af bl.a. vedvarende energi og energieffektivitet og udfasning af subsidier til fossile brændsler.

POLITIK: Klimaforhandlingerne arbejder nu frem mod en ny stor aftale, COP21, der afholdes $i 2015$ i Paris. Det er målsatningen, ligesom det var tilfaldet med COP15 $i \mathrm{Ko}$ benhavn, at alle verdens lande skal blive enige om en global og juridisk bindende aftale, der skal trade i kraft fra 2020. Hvordan forhindrer man en gentagelse af sammenbruddet fra COP15, og hvorfor skulle der vare grund til at tro, at det lykkes denne gang?

Martin Lidegaard: Selvom det ikke er en garanti for succes, så har vi simpelthen ikke råd til at fejle. Samtidig ser jeg tegn på fremskridt ude i verden. Præsident Obama annoncerede i sin tale i juni, at man fra amerikansk side nu vil tage ansvar for klimaforandringerne i form af en sammenhængende klimaplan. I Kina er man begyndt at tænke i forøget energieffektivitet og vedvarende energi. Faktisk efterspørger man fra kinesisk side danske kompetencer, og så sent som i juni besøgte jeg Kina, hvor jeg underskrev en ny samarbejdsaftale mellem Danmark og Kina med fokus på energieffektivitet. På netop dette område kan danske erfaringer afhjælpe mange af de energiudfordringer, Kina står over for. Så det gør mig fortrøstningsfuld, at mange af de store aktører er ved at gøre deres hjemmearbejde i form af nationale politikker, der kan udgøre grundstene til internationale forpligtelser. Men det er også sådan, at der stadig er nogle, der spiller Sorteper, fordi mange lande stadig tror, at bekæmpelsen af klimaforandringer er dyr. Men hvad der forekommer dyrt nu, kan på længere sigt vise sig at være billigt, også politisk. Luftforureningen i de kinesiske storbyer kan for eksempel forventes at medføre store politiske omkostninger, da den kinesiske middelklasse vil lægge mere og mere pres på de kinesiske politikere og kræve handling.

POLITIK: Hvordan måles succes ud over indgåelse af en global aftale?

Martin Lidegaard: Det vigtigste for mig er, at alle lande kommer med denne gang. Ellers kan det simpelthen ikke lade sig gøre at nå 2-graders-målsætningen. Aftalen bør være fleksibel, så ambitionsniveauet for reduktioner kan opskaleres senere. Der er stadig økonomisk krise mange steder - derfor er det utopi at tro, at alle lande vil forpligte sig til deres maksimale ambitionsniveau allerede i 2015. Derudover bør den være effektiv og omfatte reduktionsforpligtelser for alle store udledere, både i- og ulande. Den bør også indeholde et spektrum over forpligtelser, dvs. at den selvfølgelig bør tage forbehold for landenes udvikling - men det er vigtigt, at alle er med.

POLITIK: Hvilken rolle spiller EU og Danmark i forhold til at sikre, at COP21 bliver en succes?

Martin Lidegaard: EU er en af de mest progressive kræfter i klimaforhandlingerne. Dels går EU selv foran ved at påtage sig bindende forpligtelser under den anden forpligtelsesperiode af Kyotoprotokollen, dels ligger EU også i front, når det handler om at tilvejebringe klima- 
finansiering til ulandene. Kombineret giver det et godt udgangspunkt for at lægge en ambitiøs linje i klimaforhandlingerne og for en konstruktiv dialog med både i- og ulande. Men der er stadig behov for mere ambition fra EU's side. Det gælder dels i forhold til reduktionsindsatsen, hvor Danmark længe har været fortaler for et 'step up' til en udledningsreduktion på 30 pct. i 2020 i forhold til 1990-niveauet, men det gælder også på klimafinansieringssiden. Fra dansk side presser vi på for at opretholde og styrke den ambitiøse linje i EU, og vi vil presse på for, at forhandlingerne om den nye aftale i 2015 hurtigst muligt kommer til at dreje sig om substans. Med hensyn til klimafinansiering så har vi fra dansk side taget teten, og vi afholder i slutningen af oktober et stort og højt profileret klimafinansieringsmøde. På mødet vil prominente ministre fra i- og ulande sammen med toneangivende finansielle institutioner drøfte, hvorledes vi får løftet og mobiliseret yderligere private investeringer til klimatiltag. Denne dagsorden er af høj prioritet for Danmark, da fremdrift inden for klimafinansiering er nødvendig for fremdrift $\mathrm{i}$ alle forhandlinger frem til COP21. Vi er fra dansk side også i tæt dialog med Frankrig som COP21vært, der har tilkendegivet at ville invitere en række nøgleparter, herunder Danmark, til uformelle drøftelser om arkitekturen i den nye aftale. Vi vil også bruge kræfter på at styrke og benytte vores interessefællesskab og dialog med progressive lande uden for EU, herunder ikke mindst i Cartagena-dialogen, den uformelle kreds af progressive i- og ulande, som mødes et par gange om året og koordinerer tæt i forhandlingerne. Danmark vil lægge sig i selen for at være $\mathrm{i}$ front $\mathrm{i}$ alliancebygningen mellem u- og ilande.

POLITIK: Klimaforhandlingerne er nu opdelt i to spor: 1) et spor, hvor landene forhandler om den globale aftale, der skal trade i kraft i 2020, og 2) et spor, hvor landene forhandler om, hvad man kan gøre frem mod 2020. Hvad er udsigterne til at opna reelle fremskridt i det andet spor?

Martin Lidegaard: Under COP18 i Doha fik EU i samarbejde med alliancen af små østater sat et vigtigt fingeraftryk på aftalen, nemlig at man i 2014 skal identificere tiltag til at øge ambitionsniveauet før 2020, og 2014 er af flere parter udråbt som 'ambitionsåret'. Der er en række begivenheder i 2014, der giver næring til disse forhåbninger, bl.a. offentliggøres IPCC's femte hovedrapport, der gennemføres en evaluering af ambitionsniveauet $i$ Kyotoprotokollen, og så har FN's generalsekretær, Ban $\mathrm{Ki}$-moon, annonceret at ville samle verdens ledere til et møde om klima i september 2014. Under det konkrete forhandlingsspor, der beskæftiger sig med indsatsen før 2020, er der foruden et fokus på at få nye og øgede re- duktionstilsagn et særligt fokus på International Cooperative Initiatives eller 'internationale samarbejdsinitiativer'. Der er tale om globale eller regionale initiativer, som ofte iværksættes uden for FN-sporet, men hvor FN-processen kan spille en rolle dels i forhold til at holde politisk fokus på initiativerne, dels ved at bringe de rette aktører og eksperter sammen og holde et overblik over mulige initiativer og de reduktioner, de leverer. Det kan for eksempel dreje sig om initiativer til at hjælpe lande med at fjerne deres støtteordninger til fossile brændsler, til at udbrede vedvarende energi eller øge energieffektiviteten. Det er min vurdering, at sådanne initiativer kan få en væsentlig betydning i perioden frem til 2020, hvor de også kan bidrage til, at flere lande kan få en fortrolighed med de grønne løsninger, som vil give dem mod på at påtage sig nye eller øgede reduktionstilsagn.

POLITIK: COP19 skal holdes i Polen i àr. Polen er i EU et af de mindst gronne lande, og Polen og Danmark har i EUsamarbejdet ikke altid varet enige, $f x$ om handteringen af ikke-brugte, tildelte kvoter under Kyoto Protokollen. Hvad forventer du af COP19 i Polen?

Martin Lidegaard: Værtsrollen drejer sig ikke mindst om at skabe rammerne for et velafholdt møde. COP19 er derfor en god mulighed for Polen til at vise sig selv frem som et land, der tager klimaforandringerne alvorligt og er med til at drive forhandlingerne frem op til den globale aftale i 2015.

POLITIK: Hvorfor er det vigtigt at inddrage virksombeder i FN-processen, og hvordan kan man gøre det?

Martin Lidegaard: Kampen mod klimaforandringerne er en god forretningsmulighed for de private investorer og virksomheder, der forstår at respondere på efterspørgslen efter løsninger og produkter, der relaterer sig til udledningsreduktioner eller klimatilpasning. Fra offentlig side kan vi fremme og imødekomme de private aktørers store engagement ved at sikre regulering og rammevilkår, der skaber incitamenter til for eksempel at gennemføre energieffektiviseringer eller investeringer i klimaløsninger i ulandene. Det er bl.a. også derfor, jeg har inviteret både offentlige og private aktører til det store klimafinansieringsmøde i oktober i København. Samarbejdet mellem de offentlige og private sektorer udgør et vigtigt element i forhandlingerne om finansieringen af den globale aftale i 2015 og drøftelserne om udformningen af Den Grønne Fond.

POLITIK: Klimapolitik er et meget komplekst område politisk, økonomisk, juridisk, etisk og samfundsmassigt. Hvilke 
globale, nationale og lokale tiltage uden for $F N$-systemet ser du som de vigtigste for at reducere udslippet af drivhusgasser tilstrakkeligt?

Martin Lidegaard: De internationale klimaforhandlinger kan selvfølgelig ikke stå alene. Regeringen har fokus på at skabe reduktioner på kort og mellemlangt sigt gennem konkret handlen. Hvis man ser på, hvem der kommer til at bruge mere og mere energi i verden, er det klart, at de store og voksende ulande er afgørende. Det er her, at langt den største del af verdens reduktionspotentialer skal findes. Danmark har sat fokus på at flytte en mindre andel af toneangivende landes klima- og energipolitik ved at styrke vores faglige samarbejde med netop de lande, som kan drage nytte af danske erfaringer og kompetencer - og vel at mærke, hvor det giver størst effekt. Energieffektivi- tet er for eksempel et fokusområde i en del af regeringens bilaterale samarbejde med toneangivende vækstøkonomier som Kina, Vietnam, Sydafrika og Mexico. Det er bilaterale samarbejder, der går i dybden og trækker på danske klima- og energipolitiske kompetencer, herunder i forbindelse med indfasning af vedvarende energi, udbredelse af fjernvarme og energieffektivt byggeri. Samtidig med at vi målretter indsatser i nogle af de vigtigste lande, fokuserer vi også på de afgørende indsatsområder på tværs af ulandene. Et eksempel på en innovativ indsats på tværs af ulandene er Danmarks partnerskab med bl.a. Verdensbanken, som har fokus på udfasning af fossile brændselssubsidier. Der er meget godt at gøre for klimaet i det danske handlingsspor, og det er klart, at vi vil arbejde progressivt videre med det, samtidig med at vi arbejder på, at tingene skal udvikle sig i FN-sporet. 